\title{
Lipid Profile, Body Mass Index and Paraoxonase 1 Activity: Do They Correlate with Paraoxonase1 192 Polymorphism in Egyptians with Coronary Heart Disease
}

\author{
${ }^{1}$ Fathy M. El Fasakhany, ${ }^{1}$ Ghada A. Abd El-Aleem, \\ ${ }^{2}$ Usama Abd. Elaziz, ${ }^{2}$ Ayman Elsaied and ${ }^{1}$ Saad A Abou-ElNoeman \\ ${ }^{1}$ Department of Medical Biochemistry, ${ }^{2}$ Department of Cardiology, \\ Faculty of Medicine, Tanta University, Tanta Egypt
}

\begin{abstract}
Serum paraoxonase (PON1) and high density lipoprotein (HDL) are tightly associated and can protect low density lipoprotein ( $L D L)$ from oxidative modifications by hydrolysis of lipid peroxides and therefore could retard the onset of atherosclerosis. The aim of the present work is to study PON1 activity and restriction fragment length polymorphism (Gln ${ }^{192}$-Arg polymorphism) in 30 Egyptian patients with angiography proven CHD and 30 control subjects. PON1 192 polymorphisms were analyzed from the genomic DNA of 30 patients and 30 healthy controls by PCR. Plasma PON1 activities were measured by the hydrolysis of paraoxon using spectrophotometer at $405 \mathrm{~nm}$. Other parameters were determined using standard biochemical tests. Distribution or frequency of PON-1 polymorphism among patients is not statistically significant compared to the PON-1 activity which was significantly lower in subjects with CHD than control subjects.
\end{abstract}

Key Words: coronary heart disease - paraoxonase - antioxidants - lipoproteins

\section{INTRODUCTION}

Coronary heart disease (CHD) has a multifactorial aetiology involving physiological, environmental and genetic factors, leading to increased susceptibility to atherosclerotic disease ${ }^{(\mathbf{1})}$. High-density lipoprotein cholesterol (HDLc) can protect against $\mathrm{CHD}$ but the underlying mechanisms are not fully understood. One mechanism is related to the antioxidant properties of HDLc ${ }^{(2)}$. HDLc appears to protect against oxidation of low-density lipoprotein cholesterol (LDLc) and oxidation of LDLc is important in the initiation and progression of atherosclerosis ${ }^{(3)}$. The antioxidant effect of HDLc is determined by its enzymes, in particular paraoxonase 1 $(\mathrm{PON} 1)^{(4)}$.

Paraoxonase-1

(PON1), aryldialkylphosphatase, EC 3.1.8.1, is a plasma enzyme with a molecular mass of $43 \mathrm{kDa}$. Human plasma PON1 is synthesized in the liver and is a $\mathrm{Ca}^{2+}$ dependent glycoprotein. PON1 is associated with HDL on which it is almost exclusively located ${ }^{(5)}$. HDL provide a vector that facilitate secretion of the enzyme by the liver essentially by offering a hydrophobic harbor for the retained signal peptide of the $\mathrm{PON}^{(6)}$. Mice lacking PON1 are highly susceptible 
to atherosclerosis and organophosphate poisoning. In vitro assay showed that PON1 and PON3 inhibit lipid peroxidation in low density lipoprotein, thus reducing level of oxidized lipids which are involved in initiation of atherosclerosis ${ }^{(7)}$. In human, PON1 gene is located on the long arm of chromosome 7 and has 2 genetic polymorphism, one at position 192 which is gln/Arg substitution $(A \rightarrow G)$ and the other at position 55 which is a methionine/leucine substitution $\quad(\mathrm{A} \rightarrow \mathrm{T})$. These polymorphisms affect hydrolytic activity of PON1 isoenzymes with respect to lipid peroxidation (5). However, conflicting results have been reported. Decreased PON1 activity has recently been attributed to be a risk factor for atherosclerotic disease ${ }^{(8)}$. A low PON1 activity has been, also, observed in CHD patients. As the relationship between altered PON1 activity and Q/R polymorphism in CHD patients is still a matter of controversy and there are no existing data for the Egyptian population, therefore in the present study the distribution of the PON1 192 polymorphisms and its effect on PON1 activity and plasma lipid parameters were examined in Egyptian CHD patients in comparison with healthy controls.

\section{SUBJECTS \& MEHODS}

\section{Subjects}

Patients in the present study were all outpatients attending Cardiology Department, Tanta University Hospital, Tanta, Egypt. All patients had angiography proven CHD, which was visually assessed. All patients had stenosis that was severe enough (more than $60 \%$ stenosis) to require intervention either by coronary angioplasty or surgery. No patients had sustained a myocardial infarction within 6 months before taking part in the study. Patients with D.M., renal or hepatic diseases were excluded from the study. 30 patients who fulfilled the inclusion criteria were studied. Fully informed consent were obtained. The control subjects consisted of 30 healthy subjects who either attended a routine health check at a general practice or at their place at work. Lack of coronary artery disease in the control population was assessed by use of a health questionnaire, exercise stress test and all had no history suggestive of coronary artery disease. Subjects with D.M. or renal or hepatic diseases were also, excluded. The demographic details of the patients and controls are shown in table (1). Venous blood was collected from all subjects between 9:00 and 11:00 A.M. after fasting from 10:00-11:00 P.M. the previous day. Sterile $\mathrm{K}_{3}$ EDTA (tripotassium ethylenediamine tetraacetic acid) coated tubes were used for the DNA extraction samples. Plasma was isolated by low speed centrifugation. White cells were removed from the buffy coat for DNA extraction. Samples were stored at $-20{ }^{\circ} \mathrm{C}$ till the time of use.

Determination of plasma lipids:

Plasma total cholesterol, HDL-C, were determined using CHOD-POD method (Spinreact, Santa Colma, Spain). Plasma triglycerides were measured by the enzymatic GPO-PAP method (Human, Wiesbaden, Germany). LDL-C was estimated using Friedwald formula: LDL-C = 
total cholesterol -(HDL cholesterol + triglycerides/5) $\mathrm{mg} / \mathrm{dl}^{\left({ }^{(9)}\right.}$. .

\section{Determination of plasma PON1 activity:}

PON1 activity was measured by adding plasma to Tris buffer (100 $\mathrm{mmol} / \mathrm{L}, \mathrm{pH} 8.0$ ) containing $2 \mathrm{mmol} / \mathrm{L}$ $\mathrm{CaCl}_{2}$ and $1 \mathrm{mmol} / \mathrm{L}$ paraoxon $(\mathrm{O}, \mathrm{O}-$ diethyl-O-nitrophenylphosphate

(Sigma chemical Co.). The rate of generation of P-nitrophenol was determined at $405 \mathrm{~nm}, 25^{\circ} \mathrm{C}$ with the use of continuously recording spectrophotometer as described previously ${ }^{(10)}$.

\section{Determination of PON1 genotype:}

DNA was extracted from peripheral leukocytes using standard procedure (Molecular cloning) ${ }^{(11)}$. Simply, the blood $(10 \mathrm{ml})$ was collected in $\mathrm{K}_{3}$ EDTA containing sterile tubes and immediately centrifuged at $1300 \mathrm{~g}$ for 15 minutes at $4{ }^{\circ} \mathrm{C}$. The supernatant was removed and by a Pasteur pipette the buffy coat was transferred carefully to another clean tube containing $5 \mathrm{ml}$ lysis buffer $[10 \mathrm{mM}$ Tris-Cl (pH 8.0), $0.1 \mathrm{M}$ EDTA(pH 8.0), 0.5\% (w/v) Sodium dodecyl sulfate (SDS) $\%$ and $20 \mathrm{ng} / \mathrm{ml}$ Dnase-free Rnase]. Tubes were incubated for 1 hour at $37{ }^{\circ} \mathrm{C}$. Then proteinase $\mathrm{K}(20 \mathrm{mg} / \mathrm{ml})$ was added to final concentration of $100 \mu \mathrm{g} / \mathrm{ml}$ and incubated at $50{ }^{\circ} \mathrm{C}$ for 3 hours with swirling. Equal volume of phenol equilibrated with $0.1 \mathrm{M}$ Tris- $\mathrm{HCl}(\mathrm{pH}$ 8.0) was added and shaken gently for 10 minutes. Tubes were centrifuged at $5000 \mathrm{~g}$ for 15 minutes at room temperature. The aqueous phase was transferred to a clean centrifuge tube and then 0.2 volume of ammonium acetate and 2 volumes ethanol were added and mixed well. DNA was isolated either by centrifugation or by a pipette tip to another tube. Then 1 $\mathrm{ml}$ of $70 \%$ ethanol was added and centrifuged for 5 minutes. The tubes were left open until ethanol is evaporated. The DNA was dissolved in a specific volume of TE $(\mathrm{pH} 8.0)$ and stored at $4{ }^{\circ} \mathrm{C}$. That genomic DNA was used as a template for PCR amplification. Two primers, the sense primer 5 ${ }^{`}$ TAT TGT TGC TGT GGG ACC TGA G 3 and antisense primer 5 CAC GCT AAA CCC AAA TAC ATC TC 3'were used for PCR amplification of $99 \mathrm{bp}$ DNA fragment covering the region containing Gln 192 or Arg 192. Aliquots of genomic DNA were used for PCR amplification as described previously $\mathbf{( 5 , 1 2 )}$. The PCR reaction mixture contained about 200 ng DNA template, $0.5 \mu \mathrm{M}$ of each primer, 1.5 $\mathrm{mM} \mathrm{MgCl}_{2}, 200 \mu \mathrm{M}$ of the $4 \mathrm{dNTP}$ and $1 \mathrm{U}$ Taq DNA polymerase (Amersham, Bioscience). After denaturing the DNA for 4 minutes at $95{ }^{\circ} \mathrm{C}$, the reaction mixture was subjected to 35 cycles of denaturing for 1 minute at $95 \mathrm{C}, 1$ minute annealing at $60{ }^{\circ} \mathrm{C}$ and 1 minute extension at $72{ }^{\circ} \mathrm{C}$. The $99 \mathrm{bp} \mathrm{PCR}$ product was digested with $8 \mathrm{U}$ AlwI restriction endonuclease (MBI Fermentas) overnight at $37^{\circ} \mathrm{C}$ and the digested products were separated by electrophoresis on $2 \%$ agarose electrophoresis and visualized using ethidium bromide. The Arg genotype contains a unique Alw1 restriction site which results in 66 and 33 bp product, whereas the Gln genotype will not be cleaved by this restriction enzyme (figure 1). 


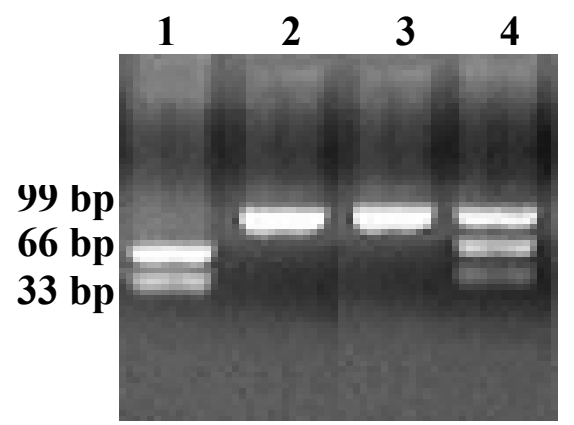

Figure.1: Agarose electrophoresis of the PCR products after cutting with Alwl restriction endonuclease. The bands were visualized using ethidium bromide and 2 $\%$ agarose (lane 1 represents $R R$ genotype, lanes 2,3 represent QQ genotype and lane 4 represents the hybrid (QR genotype)

Statistical analysis: were performed using SPSS for windows version 10.0 (SPSS Inc, Chicago. IL, USA). Student's t test, ANOVA and Scheffe post hoc test were used to compare mean values of continuous variable in cases and control, whereas $\chi^{2}$ analysis was used to compare categorical data. Correlation between variables was evaluated using Pearson (r) correlation coefficient. Relative risk was performed to examine genotype risk contribution.

\section{RESULTS}

Table (1) shows age, BMI and basic laboratory parameters of the studied population. Patients were insignificantly different from control as regards body mass index (BMI). However, compared with normal subjects, patients had significantly higher levels of total cholesterol, triglycerides and $\mathrm{LDL}-\mathrm{C}$. In contrast HDL-C level was significantly lower in the patient group compared to the control. The PON1 activity was significantly lower in patients with CHD compared with the control group whatever the genotype. PON1 activity was $60 \%$ less in CHD population. 
Table (1): Comparison between patients and control regarding different studied Parameters (mean $\pm \mathrm{SD}$ ).

\begin{tabular}{|l|c|c|c|}
\hline Parameter & Control group & Patients group & p-value \\
\hline Age, years & $47.8 \pm 5.6$ & $53.5 \pm 7.3$ & $0.0061^{*}$ \\
\hline BMI, Kg/m & $24.51 \pm 1.97$ & $25.15 \pm 1.46$ & 0.085 \\
\hline T. cholesterol, mg/dl. & $199.1 \pm 20.6$ & $216.5 \pm 29.0$ & $0.0049^{*}$ \\
\hline Triglycerides, mg/dl. & $96.5 \pm 19.9$ & $191.0 \pm 59.9$ & $0.00001^{*}$ \\
\hline HDL-C, mg/dl. & $47.46 \pm 3.77$ & $42.25 \pm 3.93$ & $0.00001^{*}$ \\
\hline LDL-C, mg/dl. & $136.8 \pm 30.4$ & $148.0 \pm 29.8$ & $0.0085^{*}$ \\
\hline PON1, nmol/min/ml & $125.3 \pm 51.4$ & $63.2 \pm 32.1$ & $0.00001^{*}$ \\
\hline
\end{tabular}

Table (2): Shows genotype analysis using restriction fragment length polymorphism frequencies of PON1 192 for QQ, RR and QR which were 0.50., 0.20 and 0.30 among CHD patients, whereas, they were $0.533,0.200$ and 0.267 among the control respectively. The allele frequency showed that $\mathrm{R}$ allele was insignificantly higher in CHD patients compared to controls.

\begin{tabular}{|c|c|c|c|c|c|c|c|c|}
\hline \multirow[t]{2}{*}{ Genotype } & \multicolumn{2}{|c|}{$\begin{array}{c}\text { Control } \\
\text { (30) }\end{array}$} & \multicolumn{2}{|c|}{ Patients } & \multirow[t]{2}{*}{ R.R. } & \multirow[t]{2}{*}{$\begin{array}{l}\text { Odd's } \\
\text { ratio }\end{array}$} & \multirow[t]{2}{*}{$\chi^{2}$} & \multirow[t]{2}{*}{ p-value } \\
\hline & $\mathrm{F}$ & $\%$ & $\mathrm{~F}$ & $\%$ & & & & \\
\hline QQ & 16 & 53.3 & 15 & 50.0 & 1.07 & 1.14 & 0.07 & NS \\
\hline RR & 6 & 20.0 & 6 & 20.0 & 1.0 & 1.0 & 0.001 & NS \\
\hline QR & 8 & 26.7 & 9 & 30.0 & 0.92 & 0.85 & 0.08 & NS \\
\hline \multicolumn{9}{|c|}{ Alleles frequency } \\
\hline & \multicolumn{2}{|c|}{ Control } & \multicolumn{3}{|c|}{ Patients } & & & \\
\hline Allele & $\mathrm{F}$ & $\%$ & $\mathrm{~F}$ & & $\%$ & & & \\
\hline $\mathbf{Q}$ & 40 & 66.7 & 39 & & 65 & & & \\
\hline $\mathbf{R}$ & 20 & 33.3 & 21 & & 35 & & & \\
\hline
\end{tabular}


Table (3): Comparison between Plasma levels of different studied biochemical parameters in different genotypes. Plasma PON 1 activity is significantly lower in RR homozygosis control and patients compared to QQ homozygosis control and patients. Also, Plasma triglycerides is significantly higher in RR homozygosis control and patients compared to QR heterozygosis control and patients and QQ homozygosis control and patients. No other level of significance was detected in plasma total cholesterol, HDL-C and LDL-C of RR patients or control compared to QR and QQ patients or control subjects.

\begin{tabular}{|c|c|c|}
\hline & Control & Patients \\
\hline \multicolumn{3}{|c|}{ Plasma Paraoxonase, $\mathrm{nmol} / \mathrm{min} / \mathrm{ml}$} \\
\hline RR & $121.4+21.5^{\mathrm{a}}$ & $46.6+29.2^{\mathrm{a}}$ \\
\hline QR & $132.6+22.8^{\mathbf{b}}$ & $45.17 \pm 13.07^{\mathrm{a}}$ \\
\hline QQ & $135.3+29.4^{\mathbf{b}}$ & $80.7+32.8^{b}$ \\
\hline p-value & $0.0021 *$ & $0.0001 *$ \\
\hline \multicolumn{3}{|c|}{ LDL-C, mg/dl } \\
\hline $\mathrm{RR}$ & $138.6+23.6$ & $157.3+17.3$ \\
\hline$\overline{Q R}$ & $133.6 \pm 22.7$ & $141.57 \pm 26.54$ \\
\hline QQ & $132.1+18.3$ & $148.1+35.6$ \\
\hline p-value & 0.103 & 0.089 \\
\hline \multicolumn{3}{|c|}{ HDL-C, mg/dl } \\
\hline RR & $48.1+3.9$ & $43.1+4.7$ \\
\hline QR & $49.3+4.1$ & $39.71+2.48$ \\
\hline QQ & $51.8+3.1$ & $43.4+3.8$ \\
\hline p- value & $0 . \overline{33}$ & $0 . \overline{107}$ \\
\hline \multicolumn{3}{|c|}{ T. Cholesterol, mg/dl. } \\
\hline $\mathrm{RR}$ & $199.3 \pm 22.1$ & $225.8 \pm 16.2$ \\
\hline QR & $197.13+20.31$ & $208.96+25.51$ \\
\hline QQ & $199.94+21.63$ & $218.5+35.7$ \\
\hline p- value & $0 . \overline{21}$ & 0.098 \\
\hline \multicolumn{3}{|c|}{ Triglycerides, mg/dl. } \\
\hline RR & $105.3+17.8^{\mathrm{a}}$ & $214.2+61.9^{\mathrm{a}}$ \\
\hline QR & $87.69 \pm 16.91^{b}$ & $171.67 \pm 40.16^{b}$ \\
\hline QQ & $98.39+21.03^{c}$ & $193.4+68.4^{\mathrm{c}}$ \\
\hline p- value & $0.0032 *$ & $0.0012 *$ \\
\hline
\end{tabular}

No significant difference was found among the same letter. 
Table (4): Correlations between different parameters in patients group

\begin{tabular}{|l|c|c|c|c|c|c|c|}
\hline & & age & BMI & T. Cholest & Triglyc. & HDL-C. & LDL-C. \\
\hline BMI & $\mathrm{r}$ & 0.119 & & & & & \\
\hline & $\mathrm{p}$ & 0.530 & & & & & \\
\hline T. Cholest & $\mathrm{r}$ & -0.097 & -0.144 & & & & \\
\hline & $\mathrm{p}$ & 0.610 & 0.447 & & & & \\
\hline Triglyc. & $\mathrm{r}$ & 0.096 & 0.074 & 0.122 & & & \\
\hline HDL-C. & $\mathrm{p}$ & 0.614 & 0.699 & 0.521 & & & \\
\hline & $\mathrm{r}$ & $\mathbf{0 . 2 6 4}$ & $\mathbf{0 . 4 1 2 *}$ & -0.046 & -0.061 & & \\
\hline LDL-C. & $\mathrm{p}$ & 0.159 & .024 & 0.809 & 0.747 & & \\
\hline & $\mathrm{r}$ & -0.138 & -0.185 & $\mathbf{0 . 9 9 2 * *}$ & 0.100 & -0.129 & \\
\hline PON1 & $\mathrm{p}$ & 0.466 & 0.327 & 0.001 & 0.600 & 0.498 & \\
\hline & $\mathrm{r}$ & 0.163 & 0.161 & -0.267 & -0.012 & -0.042 & -0.245 \\
\hline
\end{tabular}

* Correlation is significant at the 0.05 level (2-tailed).

** Correlation is significant at the 0.01 level (2-tailed).

\section{DISCUSSION}

The results of the present study showed that BMI was insignificantly higher in diseased group compared to the control group. This result is in a agreement with that reported by Odawara et $a^{(13)}$ and Aubo et $a^{(14)}$. However other authors had reported a significant increase in BMI in CHD group compared to the control group $^{(5,15)}$. The result of lipid profile of the present study confirmed the results of previous reports and went further step to include genotypes and the activity of PON1. The results of the present work showed significant increase in plasma levels of total cholesterol, triglycerides and LDL-C, with significant decrease in plasma levels of HDL-C in patients when compared with the control group (table 1). These results were in concordance with that obtained by previous reports ${ }^{(16,17,)}$. These lipid abnormalities contribute to increasing oxidative stress and may directly inhibit endothelial nitric oxide synthase (eNOS) activity that is known as a critical endotheliumderived vasoactive factor with vasodilatory and anti-atherosclerotic properties $^{(\mathbf{1 8 )}}$.

PON1 is an esterase almost exclusively located on HDL ${ }^{(4,19)}$. Investigators have attempted to demonstrate that plasma paraoxonase decreases the risk of coronary artery disease by destroying proinflammatory molecules involved in the initiation and progression of atherosclerotic lesions ${ }^{(19)}$. The antiatherogenic potential of paraoxonase is derived from its capacity to hydrolyze oxidized lipids, phospholipids, and cholesterol ester hydroperoxides, thus preventing them from accumulating in LDL particles. In vitro studies have shown that paraoxonase activity prevents oxidation of LDL particles (20) and 
even oxidation of the HDL particles themselves ${ }^{(21)}$.

The current results showed that there was a significant decrease in PON1 activity in CHD group if compared with the control group (table 1). This is in accordance with van Himbergen et $a^{(22)}$, Singh et $\boldsymbol{a l} \boldsymbol{l}^{(23)}$, and Mackness et $\boldsymbol{a l ^ { ( 9 ) }}$. On the other hand, Rahmani et al ${ }^{(16)}$ found no significant difference between control and that of CHD patients in Iranians and this supported the concept of interethnic variability in PON1 polymorphism. To our knowledge this is the first report to measure the PON1 activity and study PON1 polymorphism in Egyptian population with CHD.

Low plasma PON1 activities were noticed when HDL concentrations are profoundly low as for example fish eye disease ${ }^{(24)}$ and Tangier disease ${ }^{(25)}$. However, in one study serum HDL concentration was only moderately decreased in IDDM and familial hypercholesterolemia; the decrease in PON1 activity was independent of the changes in $\mathrm{HDL}^{(26)}$.

Several studies have shown that PON1 activity is a stronger predictor of CHD than PON1 genotypes ${ }^{(\mathbf{9}, 27)}$. However, plasma PON1 level and activity can be modified by life-style determinants like smoking, vitamin $\mathrm{E}$ consumption and intake of proatherogenic diet ${ }^{(\mathbf{2 8 - 3 0 )}}$. Some studies reported that PON1 $\mathrm{Gln}^{192} \mathrm{Arg}$ genotypes are presented at a higher frequency in $\mathrm{CHD}$, leading to the hypothesis that PON1 192 genetic polymorphism might be a risk factor for atherosclerosis ${ }^{(13,15,31,32)}$. Multiple logistic regression analysis further revealed that this association was independent of gender and conventional risk factors for CHD. However, some other studies failed to find such relationship ${ }^{(9)}$. The distribution of the alleles in the current studied groups (control and CHD) showed that the QQ genotype is the most predominant one followed by QR genotype and then RR genotype. There was no significant difference between control and CHD groups regarding genotype frequency of PON1 (table 2). Inconsistent results have been observed regarding this observation, supporting the present finding were the work published by Herrmann et $a l^{(33)}$, Ko et $a l^{(34)}$ and Aubo et $\boldsymbol{a l}^{(\mathbf{1 4})}$. Observations of discrepancies between studies may raise some interesting considerations; first, admixture of genetically heterogeneous populations could explain some contradictory results, but it cannot explain the differences found in studies conducted in the same ethnic population, i.e. Caucasians $^{(\mathbf{1})}$ or Japanese ${ }^{(\mathbf{1 3})}$. Second, discrepancies between studies may be due to a bias in patient selection. PON1 192 polymorphism may reflect an underlying unknown mutation responsible for cardiovascular risk located in the same gene or in others. It is, also, conceivable that PON1 192 polymorphism only produces an effect on coronary heart disease risk among particular subgroups of patients in the presence of additional factors that may have different prevalence among populations. In this respect, the possible deleterious effect of PON1 192 polymorphism may be overexpressed when a particular genetic variant and a particular 
oxidative condition coexist ${ }^{(19)}$. Among factors which may be associated with increased oxidative risk, dyslipidemic status and diabetes mellitus emerge as firm candidates. Further studies are needed to clarify whether paraoxonase is involved in atherosclerosis by preventing lipid oxidation in the circulation only or there may be other mechanisms linking paraoxonase to CHD.

In the present study the PON1 activity in CHD patients with RR genotype was significantly lower than patients with QQ genotypes (table 3). This observation confirms the work of Rozek et $\boldsymbol{a l}^{(\mathbf{3 5})}$. The PONl $\mathrm{R}$ allele appears to have a lower capacity to protect against LDL oxidation than the PONl Q allele. One may, in consequence, make a hypothesis that the $\mathrm{R}$ allele with low capacity against LDL oxidation may promote 'oxidative stress' and in turn, might increase cardiovascular risk.

The plasma triglycerides were significantly higher in CHD patients with RR genotype compared to QQ genotypes. This results was in accordance with that of Rozek et al ${ }^{(35)}$. On the other hand Nevin et $\boldsymbol{a l}^{(36)}$ and Hegele et $\boldsymbol{a l}^{(37)}$ could not find difference in their studies. In the control group there was no significant difference in the lipid profile between different genotypes except the RR genotype which showed a significantly higher level of TG than the QQ type (table 3). Accumulating evidence indicating that hypertriglyceridaemia (HTG) is a risk factor for cardiovascular disease. This increased risk is probably substantially mediated through the metabolic interrelationships between plasma triglyceride (TG) levels and other risk factors, such as the atherogenic lipid profile (low HDL-C levels and elevated small dense LDLC levels).

Furthermore, the present study showed positive correlations between LDL-C and plasma total cholesterol and between HLD-C and BMI in CHD group (table 4). Increasing BMI may be accompanied by increasing food intake especially fat rich food. It is logic to find a positive correlation between LDL-C and total cholesterol because LDL-C has high content of cholesterol and any increase in total cholesterol is accompanied by increase in LDL-C in CHD.

On the other hand, many results showed that the $\mathrm{R}$ allele is more dominant in CHD patients ${ }^{(1,38,39)}$. In Mexican population the genotype QR was the predominant one followed by the QQ then $\mathrm{RR}^{(\mathbf{4 0})}$ and in Japanese people the $\mathrm{R}$ containing genotype is more predominant than the QQ genotype ${ }^{(13)}$. In Netherlands Leus et $\boldsymbol{a l} \mathbf{I}^{(\mathbf{4 1})}$ found that the QQ genotype is almost double the $\mathrm{R}$ containing genotype and in England, Mackness et $\boldsymbol{a l} \mathbf{I}^{(\mathbf{8})}$ found, also, that the QQ was the predominate genotype in the population.

In conclusion, it is shown that PON1 activities toward paraoxon are lower in subjects with CHD than in control subjects regardless the PON1 genotype although the PON1 activity is much lower in RR genotype than QQ genotype.

The number of patients and control subjects analyzed was not large in the present study, so this may be the reason why we could not get significant data about genotype 
distribution. The next plan is to study the PON1 polymorphism in large scale of Egyptian population and determine whether there is a link between the enzyme activity and PON1 polymorphism.

\section{REFERENCES}

1. Lawlor DA, Day IN, Gaunt TR, Hinks LJ, Briggs PJ, Kiessling M, Timpson N, Smith GD, and Ebrahim S (2004): The association of the PON1 Q192R polymorphism with coronary heart disease: findings from the British Women's Heart and Health cohort study and a metaanalysis BMC Genet., 23;5:17.

2. Parthasarathy $S$, Barnett $J$, and Fong LG (1990): High-density lipoprotein inhibits the oxidative modification of low-density lipoprotein. Biochim. Biophys. Acta, 22;1044(2):275-83

3. Mackness MI, Abbott C, Arrol $S$, and Durrington PN (1993): The role of high-density lipoprotein and lipid-soluble antioxidant vitamins in inhibiting low-density lipoprotein oxidation. Biochem. J. ;294 (3):829-34

4. Durrington PN, Mackness B, and Mackness MI (2001): Paraoxonase and atherosclerosis. Arterioscler. Thromb. Vasc. Biol.;21(4):473-80.

5. Agachan B, Yilmaz H, Ergen HA, Karaali ZE, and Isbir T (2005): Paraoxonase (PON1) 55 and 192 polymorphism and its effects to oxidant-antioxidant system in turkish patients with type 2 diabetes mellitus. Physiol. Res.; 54(3):287-93.
6. Blatter Garin MC, Moren X, and James RW (2006): Paraoxonase- 1 and serum concentrations of HDL-cholesterol and apoA-I. J. Lipid Res.; 47(3):51520.

7. Harel M, Aharoni A, Gaidukov L, Brumshtein B, Khersonsky O, Meged R, Dvir H, Ravelli RB, McCarthy A, Toker L, Silman I, Sussman JL, and Tawfik DS (2004): Structure and evolution of the serum paraoxonase family of detoxifying and antiatherosclerotic enzymes. Nat. Struct. Mol. Biol.; 11(5):412-9.

8. Mackness B, Mackness MI, Arrol S, Turkie W, and Durrington PN (1998): Effect of the human serum paraoxonase 55 and 192 genetic polymorphisms on the protection by high density lipoprotein against low density lipoprotein oxidative modification. FEBS Lett. 13;423(1):57-60.

9. Mackness B, Davies GK, Turkie W, Lee E, Roberts DH, Hill E, Roberts C, Durrington PN, and Mackness MI (2001): Paraoxonase status in coronary heart disease: are activity and concentration more important than genotype? Arterioscler. Thromb. Vasc. Biol. ;21(9):14517.

10. Mackness MI, Harty D, Bhatnagar D, Winocour PH, Arrol S, Ishola $M$, and Durrington PN (1991): Serum paraoxonase activity in familial hypercholesterolaemia and insulin-dependent diabetes mellitus. Atherosclerosis; 86(23):193-9. 
11. Josef S, and David W R (2001): Molecular cloning: a laboratory manual. $3^{\text {rd }}$. edition, Cold Spring Harbor, New york.

12. Adkins S, Gan KN, Mody M, and La Du BN (1993): Molecular basis for the polymorphic forms of human serum paraoxonase/arylesterase: glutamine or arginine at position 191, for the respective A or B allozymes. Am J Hum Genet.; 52(3):598-608.

13. Odawara $M$, Tachi $Y$, and Yamashita K (1997): Paraoxonase polymorphism $\left(\mathrm{Gln}{ }^{192}-\mathrm{Arg}\right)$ is associated with coronary heart disease in Japanese noninsulin-dependent diabetes mellitus. J. Clin. Endocrinol. Metab. ;82(7):225760.

14. Aubó C, Sentí M, Marrugat J, Tomás M, Vila J, Sala J, and Masiá $R$ (2000): Risk of myocardial infarction associated with Gln/Arg 192 polymorphism in the human paraoxonase gene and diabetes mellitus. Eur. Heart J.;21(1):33-8.

15. Sanghera DK, Saha N, Aston CE, and Kamboh MI (1997): Genetic polymorphism of paraoxonase and the risk of coronary heart disease. Arterioscler. Thromb. Vasc. Biol. ;17(6):1067-73.

16. Rahmani M, Raiszadeh F, Allahverdian S, Kiaii S, Navab M, and Azizi F (2002): Coronary artery disease is associated with the ratio of apolipoprotein A-I/B and serum concentration of apolipoprotein B, but not with paraoxonase enzyme activity in
Iranian subjects. Atherosclerosis;162(2):381-9.

17. Gur M, Aslan M, Yildiz A, Demirbag R, Yilmaz R, Selek S, Erel O, and Ozdogru I (2006): Paraoxonase and arylesterase activities in coronary artery disease. Eur. J. Clin. Invest. ;36(11):779-87.

18. Delgado Alves J, Mason LJ, Ames PR, Chen PP, Rauch J, Levine JS, Subang $R$, and Isenberg DA (2005): Antiphospholipid antibodies are associated with enhanced oxidative stress, decreased plasma nitric oxide and paraoxonase activity in an experimental mouse model. Rheumatology ;44(10):1238-44.

19. Rodríguez Esparragón F, Hernández Trujillo Y, Macías Reyes A, Hernández Ortega E, Medina A, and Rodríguez Pérez JC (2006): Concerning the significance of paraoxonase-1 and SR-B1 genes in atherosclerosis. Rev. Esp. Cardiol. ;59(2):154-64.

20. Mackness MI, Arrol S, and Durrington PN (1991): Paraoxonase prevents accumulation of lipoperoxides in low density lipoprotein. FEBS Lett.;286:152-4.

21. Aviram M, Rosenblat $M$, Bisgaier CL, Newton RS, Primo-Parmo SL, and la Du BN (1998): Paraoxonase inhibits high density lipoprotein oxidation and preserves its functions. A possible peroxidative role for paraoxonase. J. Clin. Invest.;101:1581-90.

22. van Himbergen TM, van der Schouw YT, Voorbij HA, van 
Tits LJ, Stalenhoef AF, Peeters PH, and Roest $M$ (2007): Paraoxonase (PON1) and the risk for coronary heart disease and myocardial infarction in a general population of Dutch women. Atherosclerosis (online manuscript).

23. Singh $S$, Venketesh $S$, Verma JS, Verma M, Lellamma CO, and Goel RC (2007): Paraoxonase (PON1) activity in north west Indian Punjabis with coronary artery disease \& type 2 diabetes mellitus. Indian J. Med. Res. ;125(6):783-7.

24. Mackness MI, Walker $\mathrm{CH}$, and Carlson LA (1987): Low Aesterase activity in serum of patients with fish-eye disease. Clin. Chem. ;33(4):587-8

25. Mackness MI, Peuchant E, Dumon MF, Walker CH, and Clerc M (1989): Absence of "A"esterase activity in the serum of a patient with Tangier disease. Clin. Biochem. ;22(6):475-8

26. Mackness MI, Harty D, Bhatnagar D, Winocour PH, Arrol S, Ishola M, and Durrington PN (1991): Serum paraoxonase activity in familial hypercholesterolaemia and insulin-dependent diabetes mellitus. Atherosclerosis; 86(23):193-9.

27. Jarvik GP, Rozek LS, Brophy VH, Hatsukami TS, Richter RJ, Schellenberg GD, and Furlong CE (2000): Paraoxonase (PON1) phenotype is a better predictor of vascular disease than is PON1(192) or PON1(55) genotype. Arterioscler. Thromb. Vasc. Biol. ;20(11):2441-7.
28. Shih DM, Gu L, Hama S, Xia YR, Navab M, Fogelman AM, and Lusis AJ (1996): Geneticdietary regulation of serum paraoxonase expression and its role in atherogenesis in a mouse model. J. Clin. Invest. 1;97(7):1630-9

29. Mackness M, Boullier A, Hennuyer N, Mackness B, Hall M, Tailleux A, Duriez P, Delfly B, Durrington P, Fruchart JC, Duverger N, Caillaud JM, and Castro G (2000): Paraoxonase activity is reduced by a proatherosclerotic diet in rabbits. Biochem Biophys Res Commun. 5;269(1):232-6.

30. Arrol S, Mackness MI, and Durrington PN (2000): Vitamin E supplementation increases the resistance of both LDL and HDL to oxidation and increases cholesteryl ester transfer activity. Atherosclerosis; 150(1):129-34.

31. Ruiz J, Blanche H, James RW, Garin MC, Vaisse C, Charpentier G, et al (1995): Gln-Arg192 polymorphism of paraoxonase and coronary heart disease in type 2 diabetes. Lancet; 346:869-72.

32. Serrato M, and Marian AJ (1995): A variant of human paraoxonase/arylesterase (HUMPONA) gene is a risk factor for coronary artery disease. J. Clin. Invest.;96:3005-8.

33. Herrmann SM, Blanc $H$, Poirier O, Arveiler D, Luc G, Evans A, Marques-Vidal $P$, Bard JM, and Cambien F (1996): The Gln/Arg polymorphism of human paraoxonase (PON 192) is not 
related to myocardial infarction in the ECTIM study. Atherosclerosis; 126:299-304.

34. Ko Y-L, Ko Y-S, Wang S-M, Hsu L-A, Chang C-J, Chu P-H, Cheng NJ, Chen WJ, Chiang CW, and Lee YS (1998): The Gln-Arg 191 polymorphism of the human paraoxonase gene is not associated with the risk of coronary artery disease among Chinese in Taiwan. Atherosclerosis; 141:259-264.

35. Rozek LS, Hatsukami TS, Richter RJ, Ranchalis J, Nakayama K, McKinstry LA, Gortner DA, Boyko E, Schellenberg GD, Furlong CE, and Jarvik GP (2005): The correlation of paraoxonase (PON1) activity with lipid and lipoprotein levels differs with vascular disease status. J. Lipid Res. ;46(9):1888-95.

36. Nevin, D., A. Zambon, C. E. Furlong, R. Richter, R. Humbert, J. E. Hokanson, and J. D. Brunzell (1996): Paraoxonase genotypes, lipoprotein lipase activity and HDL. Arterioscler. Thromb. Vasc. Biol. 16: 1243-1249.

37. Hegele, R. A., J. H. Brunt, and P. W. Connelly (1995b): A polymorphism of the paraoxonase gene associated with variation in plasma lipoproteins in a genetic isolate. Arterioscler. Thromb. Vasc. Biol. 15: 89-95.

38. Heijmans $B$, Westendorp $G$, Lagaay A, Knook D, Kluft C, and Slagboom $P$ (2000): Common paraoxonase gene variants, mortality risk and fatal cardiovascular events in elderly subjects. Atherosclerosis, 149:9197.

39. Voetsch B, Benke KS, Damasceno BP, Siqueira LH, and Loscalzo J (2002): Paraoxonase 192 Gln-->Arg polymorphism: an independent risk factor for nonfatal arterial ischemic stroke among young adults. Stroke; 33(6):1459-64.

40. Imai Y, Marita H, Kurihara H, Sugiyama T, Kato N, Ebihara A, Hamada C, Kurihara Y, Shindo T, and Oh-hashi Y, et al (2000): Evidence for association between paraoxonase gene polymorphisms and atherosclerotic diseases. Atherosclerosis; 149:435-442.

41. Leus FR, Zwart M, Kastelein JJ, Voorbij HA (2001): PON2 gene variants are associated with clinical manifestations of cardiovascular disease in familial hypercholesterolemia patients. Atherosclerosis; 15;154(3):641-9. 


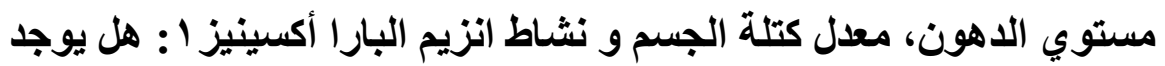

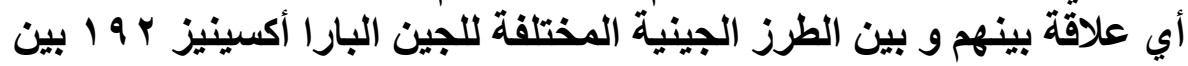
المرضى المصريين المصابين بمرض قصور الثريان التاجي

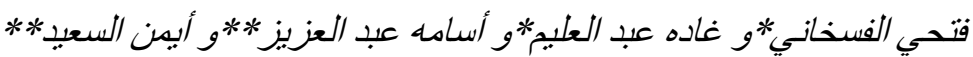

$$
\begin{aligned}
& \text { * وسعد /بو النعدان / }
\end{aligned}
$$

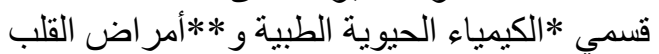

$$
\begin{aligned}
& \text { كلية الطب- جامعة طنطا }
\end{aligned}
$$

يعتبر انزيم البارا أكسينيز من الانزيمات الهضادة للأكسدة والمرتبطة بدهون الدم عالية الكثافة.

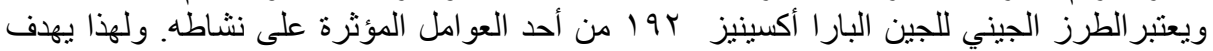

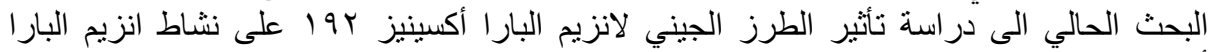

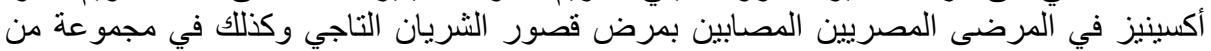

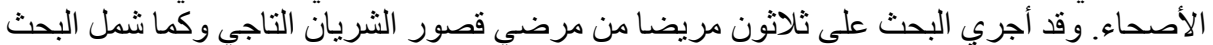

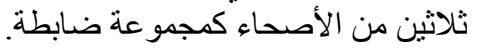

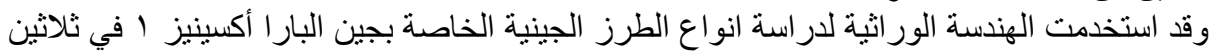

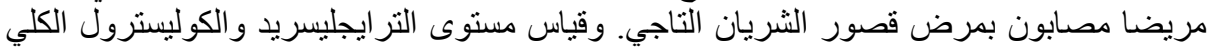

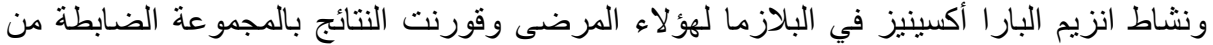

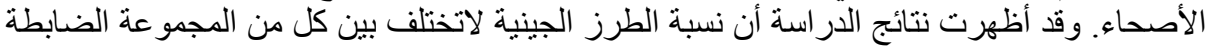

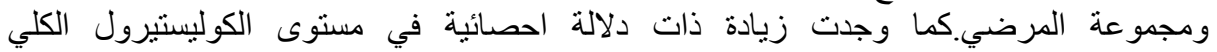

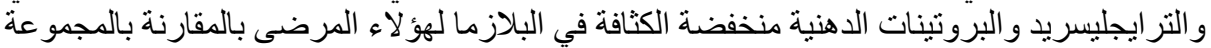

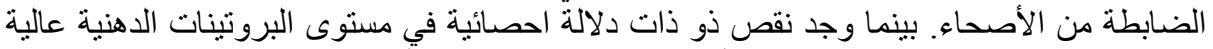

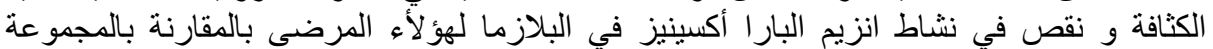

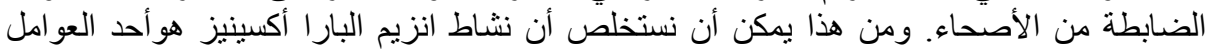
المسبية لزيادة أكسدة دهون الأم وحدوث مرض فئ أنسور الثريان التاجي. 